\title{
Effect of nitric oxide on proliferation of human retina pigment epithelial cells
}

\begin{abstract}
Purpose To investigate the effects of exogenous and endogenous nitric oxide (NO) on the proliferation of human retina pigment epithelial (RPE) cells.

Methods We stimulated cultured human RPE cells with 3-morphosydnonimine (SIN-1) to analyse the effect of exogenous NO. Incubation with a cytokine cocktail (interleukin 1- $\beta+$ interferon $\gamma+$ tumour necrosis factor $\alpha$ ) plus lipopolysaccharide (LPS) induced cells to synthesise NO endogenously. The cultures were then incubated for $48 \mathrm{~h}$, after which the cells were stained with crystal violet and absorbance at $550 \mathrm{~nm}$ was measured spectrophotometrically. Results SIN-1 inhibited human RPE cell proliferation, while haemoglobin, an NO inhibitor, almost completely blocked the inhibitory effect. On the other hand, treatment with the cytokine cocktail plus LPS did not inhibit RPE cell proliferation.

Conclusion These findings confirm that exogenous NO inhibits human RPE cell proliferation, while endogenous NO has no such blocking effect.
\end{abstract}

Key words Nitric oxide, Proliferation, Retina, Retina pigment epithelial cells

Nitric oxide (NO) is a free radical that is synthesised from L-arginine by the enzyme NO synthase. ${ }^{1} \mathrm{NO}$ is a double-edged sword. ${ }^{2}$ Produced by mammalian cells at an appropriate magnitude and tempo, it is not only a key signalling molecule in physiological processes but also plays roles in host defence, neural communication and vascular regulation. ${ }^{1-5}$ On the other hand, NO is a causal factor in, or contributor to, vascular shock, ${ }^{6,7}$ stroke, ${ }^{2}$ diabetes, ${ }^{8,9}$ neurodegeneration, ${ }^{2}$ arthritis, ${ }^{10}$ inflammation ${ }^{11,12}$ and uveitis. ${ }^{13}$ This agent also inhibits mitogenesis and halts the proliferation of mesangial, ${ }^{14}$ vascular smooth muscle, ${ }^{15}$ glial $^{6}$ and tumour cells. ${ }^{17}$ Furthermore, NO has been proven to have an inhibitory effect on the proliferation of bovine retina pigment epithelial (RPE) cells. ${ }^{18} \mathrm{RPE}$ cells play a pivotal role in the pathogenesis of proliferative

vitreoretinopathy ${ }^{19}$ and autoimmune

uveoretinitis ${ }^{20}$ in addition to carrying out other functions.

In this study we investigated the effects of exogenous and endogenous $\mathrm{NO}$ on the proliferation of human RPE cells. Cultured human RPE cells were stimulated with the NOreleasing agent 3-morphosydnonimine (exogenous NO) and were also induced to produce NO through treatment with a cytokine cocktail plus lipopolysaccharide (endogenous NO). Changes in cell proliferation were then analysed.

Materials and methods

\section{Materials}

3-Morphosydnonimine (SIN-1), haemoglobin $(\mathrm{Hb}), N \omega$-nitro-L-arginine-methyl-ester (L-Name) and lipopolysaccharide (LPS) from Salmonella typhimurium were purchased from Sigma (St Louis, MO). Human recombinant interleukin 1- $\beta$ (IL-1- $\beta$ ), interferon $\gamma$ (IFN $\gamma$ ), and tumour necrosis factor $\alpha$ (TNF $\alpha$ ) were obtained from Boehringer Mannheim (Mannheim, Germany).

\section{Cell cultures and method}

Human RPE cells were acquired from keratoplasty donor eyes and were cultured in minimal essential medium (MEM D-Val, Sigma) containing $10 \%$ fetal calf serum and antibiotics, as previously described. ${ }^{21}$ Cells were used between the second and sixth passage. Subcultured human RPE cells were transferred into 96-well plates at $10^{4}$ cells per well. After $24 \mathrm{~h}$, the original medium was discarded and various concentrations of SIN-1 with and without haemoglobin were added. In another set of experiments, a cytokine cocktail (IL-1- $\beta+$ IFN $\gamma+\mathrm{TNF} \alpha$ ) plus LPS, with and without L-Name, was added to the RPE cell cultures. The cultures were then incubated for $48 \mathrm{~h}$, after which the cells were stained with crystal violet and absorbance at $550 \mathrm{~nm}$ was measured spectrophotometrically.
G. Yilmaz

Baskent University,

School of Medicine

Department of

Ophthalmology

Ankara, Turkey

P. Esser

N. Kociek

K. Heimann

Department of Vitreoretinal Surgery

University Eye Hospital

University of Cologne

Cologne, Germany

Dr Gürsel Yilmaz

Baskent University,

School of Medicine

Department of

Ophthalmology

10.Sok. 06490 Bahçelievler

Ankara, Turkey

Tel: +903122150349

Fax: +903122237333

e-mail:

gurselyilmaz@hotmail.com

This work was supported by Köln Fortune, Deutsche

Forschungsgemeinschaft

(Es 82/5-1, He 840/6-2) and

Turkish Scientific and

Technical Research Council

Received: 13 April 2000

Accepted in revised form:

14 July 2000 


\section{Nitrite formation}

Cells were treated with cytokine cocktail plus LPS at the indicated concentration in MEM. After $48 \mathrm{~h}$, the amount of nitrite in cell-free culture supernatants was measured using the spectrophotometric method, based on the Griess reaction. ${ }^{22}$ Briefly, samples were reacted with $1 \%$ sulphanilamide and $0.1 \%$ naphthyl-ethylenediamine at room temperature. The nitrite concentration was then determined from a comparison of absorbance at $550 \mathrm{~nm}$ with that of standard solutions of sodium nitrite in MEM. Background absorbance was measured using the medium alone, and was subtracted from all values. Also the amount of nitrite produced in response to the addition of different concentrations of SIN-1 was measured.

\section{Statistical analysis}

Data was analysed using the Student's $t$-test and $p$ values $<0.05$ were considered significant. Results are expressed as mean \pm SEM.

\section{Results}

\section{Effect of SIN-1 on RPE cell proliferation}

We tested the effect of SIN-1, a compound known to spotaneously release NO in media that contain RPE cells, on cultured human RPE cells. The ability of $\mathrm{Hb}$ to inhibit $\mathrm{NO}$ activity has already been demonstrated, ${ }^{1}$ so we compared the effects of SIN-1 alone and in combination with $\mathrm{Hb}$. When applied on its own, SIN-1 inhibited cell proliferation in a dose-dependent manner, but combination with $\mathrm{Hb}$ almost completely reversed this inhibitory effect. This proved that NO was responsible

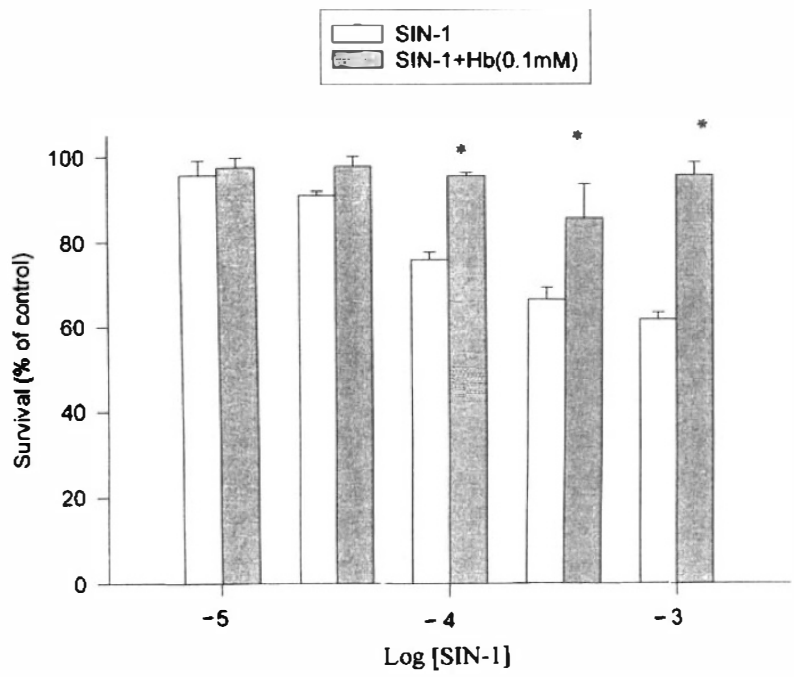

Fig. 1. Concentration-dependent effect of SIN-1 on human RPE cell proliferation. $10^{4}$ human RPE cells were adhered to 96-well plates for $24 \mathrm{~h}$. They were subsequently exposed to varying concentrations of SIN-1 alone (open bars) and in combination with $\mathrm{Hb}$ (grey bars) for $48 \mathrm{~h}$. Cell survival was assessed under crystal violet staining. Data are expressed as mean percentage survival compared with untreated cultures. Results are listed as the mean \pm SEM of three separate experiments, each of which was performed in triplicate. ${ }^{*} \mathrm{p}<0.05$.

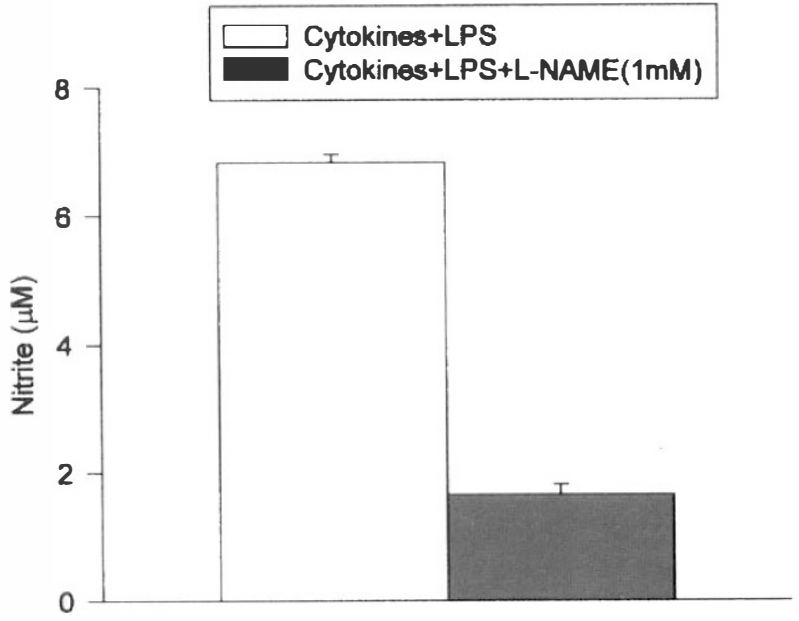

Fig. 2. Effect of a cytokine cocktail plus LPS on NO production by human RPE cells. RPE cells were incubated with the indicated combinations of IL-1- $\beta 100 \mathrm{U} / \mathrm{ml}+I F N \gamma 200 \mathrm{U} / \mathrm{ml}+T N F \alpha 200 \mathrm{U} / \mathrm{ml}$ plus LPS $10 \mu / \mathrm{ml}$, with L-Name (black bar) and without (open bar). After $48 \mathrm{~h}$, the nitrite level in culture supernatants was measured using Griess reagent. Values are listed as mean $\pm S E M$ for three experiments, each carried out in triplicate.

for the anti-proliferative effect (Fig. 1). As Fig. 1 illustrates, exogenous NO inhibited RPE cell proliferation over $5 \times 10^{-5} \mathrm{M}$ concentrations. The nitrite levels corresponding the SIN-1 concentrations of $10^{-3} \mathrm{M}, 5 \times$ $10^{-4} \mathrm{M}, 10^{-4}, 5 \times 10^{-5}$ and $10^{-5} \mathrm{M}$ were $37.5 \mu \mathrm{M}, 33.2 \mu \mathrm{M}$, $18.3 \mu \mathrm{M}, 5.6 \mu \mathrm{M}$ and $0.2 \mu \mathrm{M}$, respectively. In other words RPE cell proliferation was inhibited over at least $5.6 \mu \mathrm{M}$ nitrite levels.

\section{Effect of the cytokine cocktail + LPS}

Cultured human RPE cells have been shown to produce NO after treatment with a cytokine cocktail. ${ }^{23,24}$

Production levels are highest when a mixture of cocktail

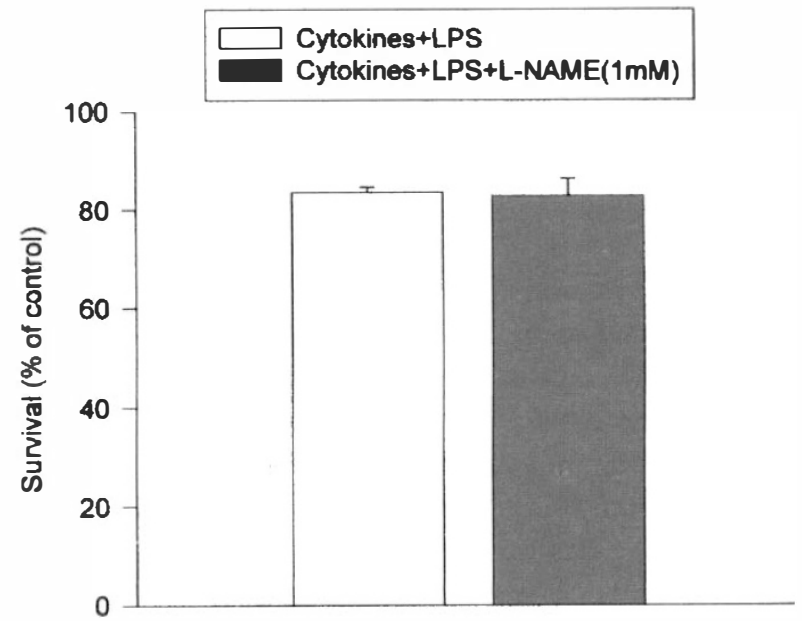

Fig. 3. Effect of cytokines plus LPS on human RPE cell proliferation. A total of $10^{4}$ human RPE cells were adhered to 96-well plates for $24 \mathrm{~h}$. These were then incubated for $48 \mathrm{~h}$ with combinations of IL-1- $\beta 100 \mathrm{U} /$ $m l+I F N \gamma 200 \mathrm{U} / \mathrm{ml}+T N F \alpha 200 \mathrm{U} / \mathrm{ml}$ plus LPS $10 \mu / \mathrm{ml}$ with L-Name (black bar) and without (open bar). Cell survival was assessed under crystal violet staining. Data are expressed as mean percentage survival compared with untreated cultures. Results are listed as the mean $\pm S E M$ of three separate experiments, each done in triplicate. 
IL-1- $\beta+$ IFN $\gamma+$ TNF $\alpha$ is used in combination with LPS, and the NO response is abolished by the nitric oxide synthase (NOS) inhibitor L-Name. ${ }^{23}$ We first tested the NO production response of RPE cells to cytokine cocktail + LPS. The cells were incubated with this mixture and biosynthesis of NO was measured based on the accumulation of the stable end-product, nitrite. Nitrite levels were measured after $48 \mathrm{~h}$ using the Griess reaction, and were rechecked after incubation with L-Name. The nitrite levels are illustrated in Fig. 2. After confirming the synthesis of nitrite in certain wells, we measured the proliferation rate in these same wells with and without L-Name (Fig. 3). As shown in Fig. 3, there was no significant difference between these two groups, which proved that endogenous NO does not affect RPE cell proliferation.

\section{Trypan blue test}

To further investigate the cytostatic/cytotoxic effect of NO on RPE cells, we tested for Trypan blue dye exclusion in cells treated with SIN-1 and cytokine cocktail, and compared these results with control data. The vast majority (>95\%) of the treated cells did not stain with Trypan blue.

\section{Discussion}

This study shows that exogenous NO inhibits human RPE cell proliferation, while endogenous NO has no such effect. The inhibitory effect was dose-dependent, and this may explain the results of endogenous NO application since the measured nitrite level in this case was below the effective critical concentration.

In our investigation, the anti-mitogenic effect of SIN-1 was reversed by the NO inhibitor $\mathrm{Hb}$, which indicates that the impact of SIN-1 was mediated by NO. Although the mechanism is unknown, it is unlikely that the antiproliferative effect of NO is due to cell death since cells treated with SIN-1 did not stain with Trypan blue.

Goureau et al. ${ }^{18}$ defined an anti-proliferative role for NO through research which demonstrated that both the NO donor SIN-1 and cytokines inhibited RPE cell proliferation in bovine cells. The present study indicates that human RPE cells differ from bovine RPE cells with regard to NO-producing agents. In contrast to bovine RPE cells, a cytokine cocktail plus LPS did not affect the proliferation of human RPE cells, despite the fact that this mixture induced NO production. Furthermore, exogenous NO inhibited the proliferation of human RPE cells in a dose-dependent fashion, while dose dependency has not been established in bovine cells. The difference in behaviour of human RPE cells versus bovine cells has been noted in some detail previously. ${ }^{23}$ As opposed to bovine RPE cells, where IFN $\gamma$ combined with either TNF $\alpha$ or LPS induces NO production, ${ }^{25}$ human RPE cells require both IL-1- $\beta$ and IFN $\gamma$ in order to produce $\mathrm{NO} .^{23}$ In addition, regulation of NOS induction by growth factors is also different in bovine cells. Basic fibroblast growth factor prevents $\mathrm{NO}$ induction in bovine RPE cells ${ }^{18}$ but has no effect in their human counterparts. ${ }^{23,24}$ Moreover, transforming growth factor $\beta$ markedly inhibits NO production in human RPE cells, ${ }^{23,24}$ while NO synthesis is only slightly increased by the same factor in bovine cells. ${ }^{18}$ All these differences could be explained by variance in cell response according to the different mediators of NO production for each cellular species. Our results also confirm that the effects of NO on RPE cell proliferation differ between species. To the best of our knowledge, ours is the first report to demonstrate the response of human RPE cells to NO during proliferation. Normally, human RPE cells are mitotically inactive; however, migration and proliferation of these cells has been shown to occur after retinal cryopexy, ${ }^{26}$ retinal laser treatment, ${ }^{27}$ penetrating trauma, ${ }^{28}$ subretinal neovascularisation ${ }^{29}$ and retinal degeneration..$^{30}$ Proliferation of RPE cells also takes place after retinal detachment, and is involved in the pathogenesis of proliferative vitreoretinopathy. ${ }^{19}$ It follows that a better understanding of the factors that control RPE cell proliferation may provide information that is relevant to normal and abnormal ocular wound healing.

Our findings confirm that exogenous NO inhibits human RPE cell proliferation. This effect could be of major importance in the regulation of ocular responses. These results may provide insight relevant to normal and abnormal ocular wound healing, and could lead to new therapeutic approaches to retinal diseases and/or unwanted reactions. Still, our findings should be interpreted with caution relative to in vivo systems because the intraocular environment involves complex interactions. Further studies are necessary to determine the mechanism of action of endogenous and exogenous $\mathrm{NO}$ in the regulation of RPE cell proliferation.

\section{References}

1. Moncada S, Palmer RMJ, Higgs EA. Nitric oxide: physiology, pathophysiology, and pharmacology. Pharmacol Rev 1991;43:109-42.

2. Gross SS. Nitric oxide: pathophysiological mechanisms. Annu Rev Physiol 1995;57:737-69.

3. Nathan C. Nitric oxide as a secretory product of mammalian cells. FASEB J 1992;6:3051-64.

4. Nathan C, Xie QW. Regulation of biosynthesis of nitric oxide. J Biol Chem 1994;269:13725-8.

5. Stuehr DJ, Griffith OW. Mammalian nitric oxide synthesis. Adv Enzymol 1992;65:287-346.

6. Kilbourn RG, Griffith OW. Inhibition of inducible nitric oxide synthase with inhibitors of tetrahydrobiopterin biosynthesis. J Natl Cancer Inst 1992;84:1671-2.

7. Kilbourn RG, Jubran A, Gross SS, Griffith OW, Lewi R. Reversal of endotoxin-mediated shock by NG. Biochem Biophys Res Commun 1990;172:1132-8.

8. Corbett JA, Lancester JR, Swetland MA, McDaniel MS. Interleukin-1 beta-induced formation of EPR-detectable ironnitrosyl complexes in islets of Langerhans. Role of nitric oxide in interleukin-1 beta-induced inhibition of insulin secretion. J Biol Chem 1991;266:21351-4.

9. Lukic ML, Stosic-Grojicic S, Ostojic N, Chan WL, Liew FY. Inhibition of nitric oxide generation affects the induction of diabetes by streptozocin in mice. Biochem Biophys Res Commun 1991;78:913-20. 
10. Farrell AJ, Blake DR, Palmer RM, Moncada S. Increased concentrations of nitrite in synovial fluid and serum samples suggest increased nitric oxide synthesis in rheumatic diseases. Ann Rheum Dis 1992;51:1219-22.

11. Ialenti A, Ianaro A, Moncada S, Di Rosa M. Modulation of acute inflammation by endogenous nitric oxide. Eur J Pharmacol 1992;211:177-82.

12. Nussler AK, Billier TR. Inflammation, immunoregulation, and inducible nitric oxide synthesis. J Leuko Biol 1993;54:171-8.

13. Goureau O, Bellot J, Thillage B, Courtois Y, De Kozak Y. Increased nitric oxide production in endotoxin-induced uveitis. J Immunol 1995;154:6518-23.

14. Garg UC, Hassid A. Inhibition of rat mesangial cell mitogenesis by nitric oxide-generating vasodilators. Am J Physiol 1989;257:F60-6.

15. Garg UC, Hassid A. Nitric oxide-generating vasodilators and 8-bromo-cyclic guanosine monophosphate inhibit mitogenesis and proliferation of cultured rat vascular smooth muscle cells. J Clin Invest 1989;83:1774-7.

16. Garg UC, Devi L, Turndorf H, Goldfrank LR, Bansinath M. Effect of nitric oxide on mitogenesis and proliferation of cerebellar glial cells. Brain Res 1992;592:208-12.

17. Stuehr D, Nathan C. Nitric oxide: a macrophage product responsible for cytostasis and respiratory inhibition in tumour target cells. J Exp Med 1989;169:1543-55.

18. Goureau O, Lepoivre M, Becquet F, Courtois Y. Differential regulation of inducible nitric oxide synthase by fibroblast growth factors and transforming growth factor beta in bovine retinal pigment epithelial cells: inverse correlation with cellular proliferation. Proc Natl Acad Sci USA 1993;90:4276-80.

19. Machemer R. Proliferative vitreoretinopathy (PVR): a personal account of its pathogenesis and treatment. Proctor lecture. Invest Ophthalmol Vis Sci 1988;29:1171-83.
20. Forrester JV. Endogenous posterior uveitis. Br J Ophthalmol 1990;74:620-3.

21. Esser P, Weller M, Bresgen M, Heimann K, Wiedemann P. The effects of basic fibroblast growth factor on bovine retinal pigment epithelium in vitro. Ger J Ophthalmol 1992;1:58-61.

22. Green LC, Wagner D, Glagowski J, Skipper PL, Wishnok J, Tannenbaum SR. Analysis of nitrate, nitrite and $\left[{ }^{15} \mathrm{~N}\right]$ nitrate in biological fluids. Anal Biochem 1982;126:131-8.

23. Goureau O, Hicks D, Courtois Y. Human retina pigment epithelial cells produce nitric oxide in response to cytokines. Biochem Biophys Res Commun 1994;198:120-6.

24. Kutty RK, Kutty G, Hooks JJ, Wiggert B, Nagineni CN. Transforming growth factor-beta inhibits the cytokine mediated expression of the inducible nitric oxide synthase mRNA in human retinal pigment epithelial cells. Biochem Biophys Res Commun 1995;215:386-93.

25. Goureau O, Lepoivre M, Courtois Y. Lipopolysaccharide and cytokines induce a macrophage-type of nitric oxide synthase in bovine retina pigmented epithelial cells. Biochem Biophys Res Commun 1992;186:854-9.

26. Lincoff $\mathrm{H}$, Kreissig I, Jacobiec F, Iwamoto T. Remodelling of the cryosurgical adhesion. Arch Ophthalmol 1981;99:1845-9.

27. L'Esperance FA. The ocular histopathologic effect of krypton and argon laser radiation. Am J Ophthalmol 1969;68:263-73.

28. Cleary PE, Ryan SJ. Experimental posterior penetrating eye injury in the rabbit. II. Histology of wound, vitreous, and retina. Br J Ophthalmol 1979;63:312-21.

29. Miller H, Miller B, Ryan SJ. The role of retinal pigment epithelium in the involution of subretinal neovascularisation. Invest Ophthalmol Vis Sci 1986;27:1644-52.

30. Gartner S, Hendkind P. Pathology of retinitis pigmentosa. Ophthalmology 1982;89:1425-32. 